\title{
STUDENTS' UNWILLINGNESS TO SPEAK IN EFL CLASSROOM FROM CULTURAL PERSPECTIVE
}

\author{
Lailatul Husna \\ Lecturer of English Education \\ Faculty of Teaccher Training and Education \\ Ekasakti University \\ Lanina_klova@yahoo.co.id
}

In the teaching and learning of English as a Foreign Language, the active participation of students in the classroom plays an important role in acquiring the target language. As claimed by Lightbown and Spada (2006) that when the students participate orally with the teachers or among their peers in the classroom it means that they are forced to be involved in the negotiation of meaning. It means that whenever the students reply to the teachers or their peers' questions and give comments, they are able to express and clarify their intentions, thoughts and opinions which are essential to language acquisition.

There is a cultural perspective affected the students unwillingness to speak in the EFL classroom. Cultural perceptions are at play right from the beginning of the language acquisition process (Kinyua: 2009). The expectations in terms of how much language and in what order it should be acquired are also determined by the culture in which the child is reared.

The aim of this research is to investigate and analyze the students' unwillingness to speak in ESL classroom based on SLA and cultural perspective. It is expected that this research could be beneficial for English teacher especially to English Foreign Language teacher to find out the causes of the students unwillingness in speaking class. The data are collected through the observation and students' speaking performance.

Keywords: unwillingness in speaking, EFL students, cultural perspetive.

\section{Introduction}

Foreign language learning is comprised of several components, including grammatical competence, communicative competence, language proficiency, as well as a change in attitudes towards one's own or another culture. For scholars and laymen alike, cultural competence, i.e., the knowledge of the conventions, customs, beliefs, and systems of meaning of another country, is indisputably an integral part of foreign language learning, and many teachers have seen it as their goal to incorporate the teaching of culture into the foreign language curriculum. It could be maintained that the notion of communicative competence, which, in the past decade or so, has blazed a trail, so to speak, in foreign language teaching, 
emphasising the role of context and the circumstances under which language can be used accurately and appropriately, 'fall[s] short of the mark when it comes to actually equipping students with the cognitive skills they need in a second-culture environment' (Straub, 1999: 2). In other words, since the wider context of language, that is, society and culture, has been reduced to a variable elusive of any definition - as many teachers and students incessantly talk about it without knowing what its exact meaning is-it stands to reason that the term communicative competence should become nothing more than an empty and meretricious word, resorted to if for no other reason than to make an "educational point." In reality, what most teachers and students seem to lose sight of is the fact that 'knowledge of the grammatical system of a language [grammatical competence] has to be complemented by understanding (sic) of culture-specific meanings [communicative or rather cultural competence]' (Byram, Morgan et al., 1994: 4).Of course, we are long past an era when first language acquisition and second or foreign language learning were cast in a "behaviouristic mould," being the products of imitation and language "drills," and language was thought of as a compendium of rules and strings of words and sentences used to form propositions about a state of affairs. In the last two decades, there has been a resurgence of interest in the study of language in relation to society, which has led to a shift of focus from behaviourism and positivism to constructivism to critical theory (see Benson \& Voller, 1997: 19-25).

One of the misconceptions that have permeated foreign language teaching is the conviction that language is merely a code and, once mastered-mainly by dint of steeping oneself into grammatical rules and some aspects of the social context in which it is embedded-'one language is essentially (albeit not easily) translatable into another' (Kramsch, 1993: 1). To a certain extent, this belief has been instrumental in promoting various approaches to foreign language teaching-pragmatic, sociolinguistic, and communicative - which have certainly endowed the study of language with a social "hue"; nevertheless, paying lip service to thesocial dynamics that undergird language without trying to identify and gain insights into the very fabric of society and culture that have come to charge language in many and varied ways can only cause misunderstanding and lead to cross-cultural miscommunication. In this case researcher focus on students unwillingness in speaking English especially within the cultural perspective.

Speaking is the first to be acquired in the process of language production. In parallel, the absence of communication apprehension and the presence of willingness to communicate are the essential prerequisites for stringing words together. Creatures of the same species communicate with one another in various ways. Man is of no exception. Speaking is among 
the most important features of human race which makes them such unique beings. Within the field of second or foreign language learning, it is believed that foreign language learners should first decide what they want to say. Next, by using appropriate structures and vocabulary, they will be able to express their ideas in a target language. The process of speaking, however, is much more complex than what it may seem at the first glance. As Mirhassani and Ghaemi (2007) stated, knowing grammatical and semantic rules, by themselves, is inadequate and learners should be aware of patterns of second or foreign language use as well as paralinguistic and nonlinguistic elements. Within the realm of classroom settings, McCroskey and Richmond (2005) considered communication as one of the basic means of learning. However, as Dörnyei (2003) stated, having high levels of second language proficiency and second language communicative competence is not enough; learners should also be willing to communicate in the second language. Thus, teachers, while attempting to help learners, should be aware of the types of contexts in which students experience high and low levels of willingness to communicate (WTC).

As well as we know that the goal of second language and foreign language learning is to facilitate better communication and understanding between individual from different cultural backgrounds and different languages. Furthermore, willingness and unwillingness of the students to communicate define themselves as Dörnyei (2003) points out, competence in the L2 may not be enough. Learners need to be not only able to communicate but also willing to communicate in the L2. Research has shown that a learner's WTC influences how frequently the learner actively engages in communicating in the L2 (Clément et al., 2003; Yashima et al., 2004). Thus MacIntyre et al. (1998) propose that WTC in L2 should be conceptualized as the primary goal of language instruction and as a comprehensive conceptual framework to describe, explain and predict L2 communication behavior.

To sum up, there is a body of evidence which paints EFL students' reluctance to speak in L2 within oral communication courses and this is one of the biggest problems widely encountered in EFL settings. There are considerable number of researches that have been conducted in order to surmount this reluctance problem among L2 students. In a study he conducted with 567 Hong Kong students, Littlewood (2004) discovered that there are 6 factors that hinder participation in the classroom. The results show that these are 1) tiredness, 2) fear of being wrong, 3) insufficient interest in the class, 4) insufficient knowledge in the subject, 5) shyness and 6) insufficient time to formulate ideas. The present study, similarly, seeks the reasons of keeping silent in English oral communication classes. The purpose of 
this study is to discover the reasons of ESL students' unwillingness to speak in their speaking subject, to shed light on the roots of these reasons and propose some strategies that can help teachers overcome the issue of acting reluctant in oral communication courses. The research questions are as follows:

1. Why are some students reluctant to speak in EFL classes?

2. is there any relationship between students' unwillingness in speaking and their culture?

\section{Speaking Ability}

Speaking has been considered as the most conspicuous kind of language ability and proficiency enabling learners to meet their basic needs. Speaking is a challenging process in which, based on the cultural and social context, speakersshould decide why, how, and when to communicate (Burns \& Seidlhofer as cited in Martínez-Flor, Usó-Juan, and Soler, 2006). Speaking has been viewed differently in the last few decades. Up to the end of the 1960s and within the environmentalist approach, speaking was mainly the result of stimulus-responsereinforcement cycles and therefore included repetition, imitation and memorization of the input in isolation. Later, with the emergence of the interactionist approach and cognitive psychology, more emphasis was put on the dynamic and interactive aspects of speaking. Functions produced by spoken language, in addition to social and contextual factors, were considered to be important. Now, due to the influence of cognitive psychology, functional, and pragmatic views of language, speaking is seen as an interactive, social, and contextualized communicative event (Martínez-Flor et al., 2006).

Foreign language anxiety consists of "self-perceptions, beliefs, feelings and behaviors related to classroom language learning arising from the uniqueness of the language learning process" (Horwitz, Horwitz and Cope 1986, 128). Foreign language learning process is a unique proccess, because learners are required to communicate using a language which they have not mastered perfectly. Three components of foreign language anxiety have been identified (Horwitz,Horwitz and Cope 1986): a) communication apprehension, b) fear of negative evaluation, and c) test anxiety. Studentswho exhibit communication apprehension do not feel comfortable communicating in the target language in front ofothers, due to their limited knowledge of the language, especially in relation to speaking and listening skills. Students who experience fear of negative evaluation do not consider language errors as a natural part of the learning process, but as a threat to their image, and a source for negative evaluations either from the teacher or their peers. As a result, they are silent and withdrawn 
most of the time, and do not participate in language activities (Ely 1986). Students who experience test anxiety consider the foreign language process, and especially oral production, as a test situation, rather than an opportunity for communication and skills improvement.In order to measure foreign language anxiety, the Foreign Language Classroom Anxiety Scale (FLCAS) has been developed, a self-report measure which assesses "the degree of anxiety, as evidenced by negative performance expectancies and social comparisons, psychophysiological symptoms, and avoidance behaviors" (Horwitz 1986, 559). Many studies have addressed the relationship between language anxiety and motivation. More specifically, integratively motivated students "are less anxious in second language contexts" (Gardner, Day and MacIntyre 1992, 212) than students who students who are instrumentally motivated. Their research findings provide indications that anxiety and motivation are "two separate dimensions with overlapping behavioral consequences" (Gardner, Day and MacIntyre 1992, 212).

As a part of language learning, it is of the basic needs of any English as a foreign language learner to know how to speak and how to communicate orally. Thus, it is essential for every classroom to spend time on individuals' speaking performance and oral communication. Among different types of classroom speaking performance, the imitative ones are of great significance as these drills offer limited practice by repetition (Brown, 2001). As Harmer (2007) pointed out, repetition enables students to fix new words or phrases in their memory. In addition, it enables them to improve on what they did before and provides them with the opportunity to think about the way they can re-word things.

Foreign language learners themselves are of different opinions regarding the cultural component of foreign language study. Some learners feel threatened in their L1 identity by too much emphasis on culture. Thus, for example, for the teaching of foreign languages in the U.S., some students say: “this is a language class. We don't want culture rammed down our throats" (Chavez, 2002). Others say: "the language classroom is not really the place to learn about values, history and culture. . some German instructors want to raise our consciousness about us being Americans. It's debilitating." (Kramsch, 2011, p. 361). I suspect that for some who come from a modest social background, a feeling of inferiority or uncertainty about their own culture might lead them to reject culture altogether from language classes. However, these same students would find it quite all right for immigrants to learn not only the language but also the culture of their host country. 


\section{Culture in Language Learning}

Culture in language learning is not an expendable fifth skill, tacked on, so to speak, to the teaching of speaking, listening, reading, and writing. It is always in the background, right from day one, ready to unsettle the good language learners when they expect it least, making evident the limitations of their hard- won communicative competence, challenging their ability to make sense of the world around them. (Kramsch, 1993: 1).

Foreign language learners themselves are have different opinions regarding the cultural component of foreign language study. Some learners feel threatened in their L1 identity by too much emphasis on culture. Thus, for example, for the teaching of foreign languages in the U.S., some students say: "this is a language class. We don't want culture rammed down our throats" (Chavez, 2002). Others say: "the language classroom is not really the place to learn about values, history and culture. . . some German instructors want to raise our consciousness about us being Americans. It's debilitating." (Kramsch, 2011, p. 361). I suspect that for some who come from a modest social background, a feeling of inferiority or uncertainty about their own culture might lead them to reject culture altogether from language classes. However, these same students would find it quite all right for immigrants to learn not only the language but also the culture of their host country.

\section{Method}

This research's purpose is to find the reason why the EFL students reluctant to speak in their speaking class. The researcher tried to find out the reasons of reluctance observed among the students who are attending speaking class in Indonesia classroom setting. The participants of this research were the students of English department of Ekasakti University who took the Speaking class. The students were asked to deliver the speech based on the topic given by the lecturer. By those performances the lecturer and researcher assesed the speaking performance based on the speaking ability rubric.

\section{Result and Discussion}

One of the substantial goals of learning a second or foreign language is that it enables individuals to better communicate and understand people who speak different languages and 
have different cultural background (Yashima, Zenuk-Nishide, \& Shimizu, 2004). Following MacIntyre, Burns, and Jessome (2011), communication in a second language is a very complex process that embraces a dynamic interplay between the context of learning and the psychology of learners. In this respect, Morreale (2007) stated that individuals should meet three requirements in order to communicate completely. These requirements include motivation, knowledge, and skill. As it can be seen, having positive motivation toward communication is of paramount importance while communicating with others. In addition, as Dörnyei (2005) mentioned, high levels of communicative competence, which is considered as one of the major aims of communicative language teaching approaches, does not necessarily mean that a person tends to engage in any communicative opportunity. In other words, there must be another factor that influences a person's communicative competence and his attempts to put that competence into practice. This factor, which is the result of a combination of a number of psychological, linguistic, and contextual variables, is called willingness to communicate.

Based on this research, the researcher found that the students unwillingness to speak in EFL classroom mainly because their limited vocabulary. Many students did not develop their speaking topic well because they did not master the basic vocabularies. The result can be seen from the table below:

Students' speaking performance score

\begin{tabular}{|l|l|l|}
\hline No & \multicolumn{1}{|c|}{ Students } & \multicolumn{1}{c|}{ Score } \\
\hline 1 & Students 1 & 65 \\
\hline 2 & Students 2 & 65 \\
\hline 3 & Students 3 & 66 \\
\hline 4 & Students 4 & 72 \\
\hline 5 & Students 5 & 73 \\
\hline 6 & Students 6 & 82 \\
\hline 7 & Students 7 & 76 \\
\hline 8 & Students 8 & 65 \\
\hline 9 & Students 9 & 65 \\
\hline 10 & Students 10 & 70 \\
\hline 11 & Students 11 & 83 \\
\hline 12 & Students 12 & 75 \\
\hline
\end{tabular}




\begin{tabular}{|l|l|l|}
\hline 13 & Students 13 & 72 \\
\hline 14 & Students 14 & 72 \\
\hline 15 & Students 15 & 82 \\
\hline 16 & Students 16 & 75 \\
\hline 17 & Students 17 & 70 \\
\hline
\end{tabular}

The result of the speaking performnce/sores shows that $60 \%$ of the students still faced the anxiety in speaking. It was affected their unwillingness to speak in the classroom. Based on the researcher interview with the lecturer it is found that the students couldn't develop their skill in speaking because of the limited of their vocabulary. Furtheremor, it did not find that the corelation between culture background and their willingness to speak in EFL classroom.

Willingness to engage in speaking activities is considered important, because unless students have ample opportunities to practice oral fluency and accuracy skills, they will not develop these skills. To measure willingness, a classroom diary was kept in which these students' willingness to participate in speaking tasks was recorded. Research findings provided strong evidence that at the end of the school term these anxious students were significantly more willing to participate in speaking activities. Apart from being willing to participate, these students did not avoid eye contact with the teacher, as they did at the beginning of the school term. Avoiding making eye contact with the teacher is a typical nonverbal reaction of anxious students (Gregersen, 2003). At the end of the school term, they were looking directly at the teacher more often and for more time. Although non-verbal communication is not as straightforward as encoded language, we attribute the change in eye contact patterns to the fact that they felt more relaxed, and eager to take part in speaking tasks.

With respect to English language speaking performance, these students showed improvement. We recorded the progress of these students and their performance in speaking tasks. Performance was measured in terms of both accuracy and fluency in a speaking test conducted at the end of the school term. Although a similar speaking test was not conducted at the beginning of the school term, improvement was evident for these students. More specifically, most students' accuracy, their “ability to produce grammatically correct sentences" (Richards, Platt, and Weber, 1985: 109) increased, mainly in relation to the use of tenses and prepositions. They still made errors, however, but in most instances this did not stop them from trying to communicate.

Their fluency, that is, "natural language use" (Brumfit, 1984: 56) also increased. At the end of the school year the exhibited many characteristics of fluency, such as increased ability to concentrate on content rather than form, and increased conversational speed, compared to the beginning of the school term. They also showed more qualities of natural 
speech, such as more appropriate use of intonation and stress, ability to produce continuous speech without breakdown of communication, which, among others, are major parameters of language fluency (Richards, Platt, and Weber, 1985: 108-109). Finally, their tendency to revert to their mother tongue when they encountered difficulty disappeared almost completely. Instead, they tried to express themselves in English, using gestures when necessary, and they developed the strategy of asking the teacher for help.

We attribute the greater part of the improvement in speaking accuracy and fluency to project work, which provided them with ample opportunities to practice language in a "natural" setting, negotiate for meaning, and helped them to develop strategies on getting their message across despite language difficulties. In accordance with Gregersen and Horwitz, we found that their suggestion that "anxious students could be taught to focus on continuing a conversation as a goal in itself whenever they make mistakes", can be facilitated by project work (Gregersen and Horwitz, 2002: 570). At this point, two points need to be clarified. First, the above interventions do not constitute "ideal" interventions to reduce foreign language speaking anxiety. They are simply an attempt to move from theory to practice, focusing on a specific learning situation. In addition, it is not suggested that interventions were necessarily successful. For example, two students showed minimal improvement in willingness to engage in speaking activities and their speaking performance increased slightly. It seems that more individualized measures were needed, since what is effective for an anxious student may not be necessarily effective for another.

\section{Conclusion}

Teachers should realise that language learning, and particularly oral production, is a potentially stressful situation for some students, and that the "tension and discomfort related to language learning call for the attention of the language teaching profession" (Horwitz, 2001: 122). The recommendations we make are congruent with previous studies suggesting that teachers should not be consider withdrawn students as lazy, lacking in motivation, or having "poor attitude" (Gregersen, 2003: 30), when in fact they suffer from anxiety. Instead, they should identify anxious learners and make interventions to help them overcome foreign language anxiety (Aida, 1994). Because foreign language speaking anxiety in the English classroom may stem from fear of making mistakes and the consequent fear of negative evaluation, and students' perception of low ability in relation to their peers, we suggest that teachers may want to consider the following interventions. First, teachers can incorporate project work, because it can provide anxious and non-anxious students alike with abundant 
opportunities to use language in a non-threatening context. We argue that the first step in reducing anxiety is to actually have students participate in speaking tasks. Because students are more eager to participate in oral activities in small groups (Young, 1990), project work can be

very helpful.

Second, the creation of a friendly classroom atmosphere is important to gain the students motivations in speaking class. In order to increase their vocabulary mastery, the lecturer may use the strategies in teaching English with better media espeacially in speaking class. Based on this research, vocabulary development of the students when speaking English was not good enough.

Third, the research also investigated the correlation between culteral background of the students and their unwillingness to speak in EFL classroom. It can be said that the ultural background of the students did not affect their performance in speaking. It can be seen from the interview held by the researcher nd the field note taking.

The final conclusion is that lecturer needs to assume the role of the researcher in their own classrooms. Before employing strategies to help students overcome foreign language speaking anxiety, foster motivation, and increase foreign language performance, practitioners should get to know their students, their attitudes toward oral production, and to shed light into the reasons that underlie their low performance and their unwillingness to engage in speaking activities. It is suggested that "teacher as a researcher" approach is an invaluable tool. Such an approach, which brings together theory and practice, can have positive effects both on the professional development of English teachers and on students' anxiety levels, motivation and language acquisition.

\section{References}

Ali, Z. 2007. Willing learners yet unwilling speakers in ESL classrooms. Asian University Journal of Education, 3(2), 57-73.

Brown, H. D. 2001. Teaching by principles: An interactive approach to language pedagogy (2nd ed.). White Plains: Pearson Education.

Dörnyei, Z. 2003. Attitudes, orientations, and motivations in language learning: advances in theory, research, and applications. Language Learning, 53(1), 3-32. http://dx.doi.org/10.1111/1467-9922.53222 
Dörnyei, Z. 2005. The Psychology of the language learner: individual differences in second language acquisition. Mahwah, New Jersey: Lawrence Erlbaum Associates

Donald, S. (2010). Learning how to speak: Reticence in the ESL classroom. ARECLS , 7, 4158.

Dwyer, E., \& Heller-Murphy, A. (1996). Japanese learners in speaking classes. Edinburgh Working Papers in Applied Linguistics, 7,46-55.

Elmes David. 2013. The relationship of language and culture. National Institute of Fitness and Sports in Kanoya International Exchange and Language Education Center

Gass. M. Susan and Larry Selinker. 2008. Second Language Acquisition: an introductory course. Library of Congress Cataloging in Publication Data

Krashen D Stephen. 2009. Principles and Practice in Second Language Acquisition. University of Southern California

Lightbown, Patsy M and Nina Spada. 2006. How Languages are Learned. New York: Oxford University Press.

MacIntyre, P. D., Burns, C., \& Jessome, A. 2011. Ambivalence about communicating in a second language: A qualitative study of French immersion students' willingness to communicate. The Modern Language Journal, 95, 81-96.

MacIntyre, P. D., Dörnyei, Z., Clément, R. \& Noels, K. A. 1998. Conceptualizing willingness to communicate in a L2: A situational model of L2 confidence and affiliation. Modern Language Journal, 82(4), 545-562.

Martínez-Flor, A., Usó-Juan, E., \& Soler, E. A. 2006. Towards acquiring communicative competence through speaking. In: E. Usó-Juan, \& A. Martínez-Flor (Eds.), Current trends in development and teaching language skills (pp. 137-157). Berlin: Mouton de Gruyter.

McCroskey, J. C. 1977. Oral communication apprehension: A summary of recent theory and research. Human Communication Research, 4(1), 78-96.

McCroskey, J. C. 1992. Reliability and validity of the willingness to communicate. Communication Quarterly, 40(1), 16-25.

McCroskey, J. C., \& Richmond, V. 2005. An introduction to communication in the classroom: The role of communication in teaching and training. Old Tappan: Pearson Education.

Mirhassani, A., \& Ghaemi, F. 2007. Language teaching theories, approaches, methods, and skills. Tehran: Kasa Kavosh. 
Rahmatollahi, Maryam \& Gholamhassan Famil Khalili. 2015. Relationship between Intermediate EFL Learners' Communication Apprehension, Willingness to

Communicate, and Speaking Ability International Journal of Applied Linguistics \& English Literature ISSN 2200-3592 (Print), ISSN 2200-3452 (Online) Vol. 4 No. 6; November 2015 Australian International Academic Centre, Australia

Tsiplakides, Iakovos \& Areti Keramida. 2009. Helping Students Overcome Foreign Language Speaking Anxiety in the English Classroom: Theoretical Issues and Practical Recommendations. International Education Studies.

Woodrow, L. 2006. Anxiety and speaking English as a second language. RELC Journal, $37(3), 308-328$.

Weaver, C. 2005. Using a rash model to develop a measure of second language learners' willingness to communicate within a language classroom. Journal of Applied Measurement, 6(4), 396-415.

Yashima, T., Zenk-Nishide, L., \& Shimizu, K. 2004. The influence of attitudes and affect on willingness to communicate and second language communication. Language Learning, 54(1), 119-152.

Zakian, M., Moradan, A., \& Naghibi, S. E. 2012. The relationship between self-, peer-, and teacher assessments of EFL learners' speaking. World J Arts, Languages, and Social Sciences, 1(1), 1-5. 